\title{
Postpartum Plasmapheresis Treatment in a Severe Liver Enzyme Disorder
}

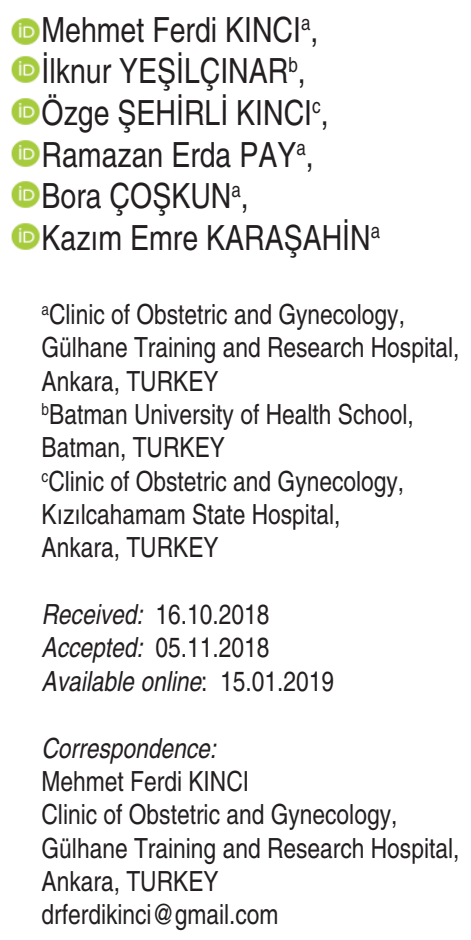

Keywords: HELLP syndrome; plasmapheresis

Copyright (C) 2018 by Türkiye Klinikleri

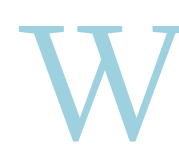

e read the article by Koyuncu et al. with interest and since we have had experience on the subject because of a long time follow up of a similar case, we wanted to present our opinion, also to contribute and underline some different points about Postpartum Plasmapheresis Treatment in HELLP syndrome. ${ }^{1}$

A 28-year-old G1P1 was admitted to our clinic at 36 weeks of gestation. The blood pressure (BP) value was 141/90 $\mathrm{mmHg}$, her platelet counts were $72 * 10$. e3/mikroL, in the biochemical examination; AST: $273 \mathrm{U} / \mathrm{L}, \mathrm{ALT}$ : 286 U/L, GGT: 74 U/L, LDH: 551 U/L, CK: 194 U/L, d-dimer: 3.34 mg/L and protein was 2 positive in spot urine, preeclampsia was diagnosed an emergency caesarean section was done (Table 1). Magnesium infusion and antihypertensive treatment were started. Plasmapheresis treatment was planned after the surgery due to 10-12 schistocytes were observed in all areas in the peripheral blood smear. 17 units of fresh frozen plasma (FFP) were used during plasmapheresis. During the follow-up period in the intensive care unit, platelet values started to increase from day 3, and AST, ALT, LDH, total bilirubin, urea and creatinine values started to return to normal on the $3^{\text {rd }}$ day (Table 1). On the $5^{\text {th }}$ day after the plasmapheresis treatment, patients all vital signs and laboratory values returned to normal and she was discharged.

Plasmapheresis treatment is an alternative treatment that can be used in HELLP syndrome. It is based on removal of antibodies, immune complexes and some toxins from plasma. Although the mechanism of action of plasmapheresis in HELLP syndrome is not fully known, it is stated that in patients with resistant HELLP syndrome and with organ failure, it increases platelet count and improves renal function. ${ }^{2}$ Plasma exchange is estimated to eliminate aggregate and procoagulant factors discharged from endothelial cells and active platelets. ${ }^{2}$ There are no definitive statements about the indications, time and frequency of plasmapheresis in the literature. When limited number of studies are examined, postpartum 24- 


\begin{tabular}{|c|c|c|c|c|c|c|}
\hline \multicolumn{7}{|c|}{ TABLE 1: Laboratory results. } \\
\hline & \multirow[b]{2}{*}{ First Application } & \multirow[b]{2}{*}{ ( $6^{\text {th }}$ hour) } & \multicolumn{2}{|c|}{ After Treatment } & \multirow[b]{2}{*}{$4^{\text {th }}$ day } & \multirow{2}{*}{$\begin{array}{c}5^{\text {th }} \text { day } \\
\text { (Before Discharge) }\end{array}$} \\
\hline & & & $1^{\text {st }}$ day & $2^{\text {nd }}$ day & & \\
\hline $\mathrm{Hb}(\mathrm{g} / \mathrm{dl})$ & 11.5 & 10.4 & 9.1 & 9.4 & 10.4 & 12.3 \\
\hline Platelet count (10.e3/mikroL) & 85 & 87 & 109 & 116 & 137 & 256 \\
\hline AST (IU) & 273 & 169 & 115 & 35 & 37 & 42 \\
\hline $\operatorname{ALT}(I U)$ & 286 & 206 & 163 & 45 & 36 & 54 \\
\hline Urea (mg/dL) & 32 & 31 & 28 & 25 & 31 & 34 \\
\hline Creatinin (mg/dL) & 0.88 & 0.88 & 0.84 & 0.86 & 0.82 & 0.86 \\
\hline PTZ (second) & 10.7 & 11.3 & - & 12 & - & - \\
\hline aPTT (second) & 33.4 & 35.4 & - & 31 & - & - \\
\hline d-dimer (mg/L) & 3.34 & - & - & - & 3.53 & 3.53 \\
\hline Fibrinogen (mg/L) & 326 & - & - & - & 277 & 134 \\
\hline
\end{tabular}

72 hours, it has been suggested to patients with platelet values below $100 * 10$ e3/microL. However it is not clear when it should be terminated, it is stated in a study that when platelets start to rise and the platelet count is $100 * 10 . \mathrm{e} 3 / \mathrm{microL}$ it can be terminated. ${ }^{2}$ We performed plasmapheresis at postpartum $12^{\text {th }}$ hour. We did not need to recur because the platelet values increased above $100 * 10 \mathrm{e} 3 / \mathrm{microL}$ at $30^{\text {th }}$ hour of plasmapheresis.

The pathophysiology and treatment of preeclampsia and HELLP syndrome are highly controversial for obstetricians. ${ }^{3}$ Plasmapheresis, which is an alternative treatment modality in HELLP syndrome, needs multidisciplinary approach such as; anesthesiologist, obstetrician, hematologist, blood banking and many equipment requiring, therefore is a difficult prosess. However, it is an alternative and life-saving treatment modality for the treatment of HELLP syndrome if it is administered with the right timing in right selected cases.

\section{Source of Finance}

During this study, no financial or spiritual support was received neither from any pharmaceutical company that has a direct connection with the research subject, nor from a company that provides or produces medical instruments and materials which may negatively affect the evaluation process of this study.

\section{Conflict of Interest}

No conflicts of interest between the authors and/or family members of the scientific and medical committee members or members of the potential conflicts of interest, counseling, expertise, working conditions, share holding and similar situations in any firm.

\section{Authorship Contributions}

Idea/Concept: Mehmet Ferdi Kıncı, Özge Şehirli Kıncı; Design: İlknur Yeşilçınar, Ramazan Erda Pay; Control/Supervision: Bora Çoşkun, Kazım Emre Karaşahin; Data Collection and/or Processing: Mehmet Ferdi Kıncı, İlknur Yeşilçınar; Analysis and/or Interpretation: Özge Şehirli Kınc1, Ramazan Erda Pay; Literature Review: Bora Çoşkun, Kazım Emre Karaşahin; Writing the Article: Mehmet Ferdi Kıncı, Ramazan Erda Pay; Critical Review: İlknur Yeşilçınar, Kazım Emre Karaşahin; References and Fundings: Özge Şehirli Kıncı, Bora Çoşkun; Materials: Mehmet Ferdi Kıncı. 


\section{REFERENCES}

1. Koyuncu K, Kan Ö, Yüce T, Taskın S, Soylemez F. Postpartum plasmapheresis treatment in a severe liver enzyme disorder. JCOG 2018;28(2):75-7.

2. Sibai BM, Ramadan MK, Usta I, Salama M, Mercer BM, Friedman SA. Maternal morbidity and mortality in 442 pregnancies with hemolysis, elevated liver enzymes, and low platelets (HELLP syndrome). Am J Obstet Gynecol 1993;169(4):1000-6.

3. Gokdemir IE, Evliyaoglu Ö, Çoskun B. The role of ADAMTS genes in preeclampsia. Turk J Obstet Gynecol 2016;13(3):149-53. 